\title{
Managing iron supply during the infection cycle of a flea borne pathogen, Bartonella henselae
}

\author{
MaFeng Liu ${ }^{1}$ and Francis Biville ${ }^{2 *}$ \\ ${ }^{1}$ Key Laboratory of Animal Disease and Human Health of Sichuan Province, Avian Disease Research Center, Institute of Preventive Veterinary Medicine, College of \\ Veterinary Medicine, Sichuan Agricultural University, Chengdu/Ya'an, Sichuan, China \\ 2 Unité des Infections Bactériennes Invasives, Département Infection et Epidémiologie, Institut Pasteur, Paris, France
}

\section{Edited by:}

Mathieu F. Cellier, Institut national de la recherche scientifique, Canada

\section{Reviewed by:}

Michael F. Minnick, The University of Montana, USA

D. Scott Merrell, Uniformed

Services University, USA

\section{*Correspondence:}

Francis Biville, Unité des Infections Bactériennes Invasives,

Département Infection et

Epidémiologie, Institut Pasteur, 28, rue du Dr. Roux, 75015 Paris, France e-mail: fbiville@pasteur.fr
Bartonella are hemotropic bacteria responsible for emerging zoonoses. Most Bartonella species appear to share a natural cycle that involves an arthropod transmission, followed by exploitation of a mammalian host in which they cause long-lasting intra-erythrocytic bacteremia. Persistence in erythrocytes is considered an adaptation to transmission by bloodsucking arthropod vectors and a strategy to obtain heme required for Bartonella growth. Bartonella genomes do not encode for siderophore biosynthesis or a complete iron $\mathrm{Fe}^{3+}$ transport system. Only genes, sharing strong homology with all components of a Fe ${ }^{2+}$ transport system, are present in Bartonella genomes. Also, Bartonella genomes encode for a complete heme transport system. Bartonella must face various environments in their hosts and vectors. In mammals, free heme and iron are rare and oxygen concentration is low. In arthropod vectors, toxic heme levels are found in the gut where oxygen concentration is high. Bartonella genomes encode for 3-5 heme-binding proteins. In Bartonella henselae heme-binding proteins were shown to be involved in heme uptake process, oxidative stress response, and survival inside endothelial cells and in the flea. In this report, we discuss the use of the heme uptake and storage system of $B$. henselae during its infection cycle. Also, we establish a comparison with the iron and heme uptake systems of Yersinia pestis used during its infection cycle.

Keywords: Bartonella, heme utilization, flea transmission, heme-binding protein, Yersinia

\section{INTRODUCTION}

Bartonella are $\alpha$-proteobacteria that employ arthropods for transmission and erythrocyte parasitism as a common parasitism strategy (Dehio and Sander, 1999; Schulein et al., 2001). Currently, 26 distinct Bartonella species have been described (Kaiser et al., 2011). Bartonella bacilliformis, Bartonella quintana, and B. henselae are the three most important human pathogens (Dehio, 2005; Florin et al., 2008; Guptill, 2010). Humans are the reservoir host for B. bacilliformis and B. quintana, in which they cause various clinical manifestations associated with both intraerythrocytic bacteremia and endothelial cell infection (Hill et al., 1992; Maurin and Raoult, 1996). The cat is the reservoir host for B. henselae (Chomel et al., 2009). B. bacilliformis causes Oroya fever and verruga peruana (Herrer, 1953a,b). B. quintana causes trench fever (Vinson et al., 1969). B. henselae causes cat scratch disease (CSD) and bacillary peliosis (Jones, 1993). Both B. quintana and $B$. henselae can cause bacillary angiomatosis usually in immunodeficient patients (Spach et al., 1995; Sander et al., 1996).

\section{Bartonella AND THEIR INFECTION CYCLE}

Each Bartonella species appears to be transmitted by specific bloodsucking arthropod vectors, and is highly adapted to one or several mammalian reservoir hosts, in which it causes longlasting intra-erythrocytic bacteremia (Schroder and Dehio, 2005). Intra-erythrocytic bacteremia caused by Bartonella in the host has been studied in different rodent models (B. birtlesii/mouse,
B. tribocorum/rat) (Boulouis et al., 2001; Schulein et al., 2001; Marignac et al., 2010). After intravenous inoculation with invitro-grown B. tribocorum, the bacteria rapidly disappeared in the circulating blood system within a few hours, and blood remained sterile for 3-4 days (Schulein et al., 2001). Endothelial cells (Dehio, 2005) or $\mathrm{CD}^{+} 4^{+}$progenitor cells (Mandle et al., 2005) were proposed as the primary niche. About 4-5 days post-infection, bacteria seeded from the primary niche to the bloodstream are able to invade mature erythrocytes (Schulein et al., 2001). Inside erythrocytes, bacteria multiply until reaching a steady number (eight bacteria per infected erythrocyte for Bartonella tribocorum in rat erythrocytes), which is maintained for the remaining lifespan of the infected cell (Schulein et al., 2001). Intra-erythrocytic bacteremia in the B. tribocorumrat model is persistent for 8-10 weeks (Schulein et al., 2001). During this period, bloodsucking arthropods mediate the transmission to other susceptible hosts. This infectious procedure was also observed in a mouse model for B. grahamii and B. birtlesii (Koesling et al., 2001; Marignac et al., 2010).

\section{IRON/HEME UPTAKE IN Bartonella}

Analysis of Bartonella genomes indicated that they neither encode for a siderophore biosynthesis pathway, nor for a complete $\mathrm{Fe}^{3+}$ transport system. Bartonella genomes encode for homologs of YfeABCD from Yersinia pestis (Perry et al., 2007) and SitABCD from avian pathogenic E. coli, both characterized as $\mathrm{Fe}^{2+}$ and 
$\mathrm{Mn}^{2+}$ inner membrane transporters (Sabri et al., 2006; Anjem et al., 2009). Bartonella genomes encode for a complete heme uptake system. This heme uptake system is comprised of HutA, an outer membrane heme transporter, HutB, HutC, and $\mathrm{HmuV}$ the three components of an inner membrane $\mathrm{ABC}$ transporter and a cytoplasmic heme degrading enzyme (HemS) (Parrow et al., 2009; Liu et al., 2012a). HutA from B. quintana contains the FRAP and NPNL domains conserved in heme transporters like HemR of Yersinia enterocolitica and HumR of Yersinia pestis (Parrow et al., 2009). Also, it was shown that HutA from $B$. quintana can apparently transport heme when expressed in $E$. coli hemA mutant strain (Parrow et al., 2009). This activity is TonB-dependent (Parrow et al., 2009). B. tribocorum and B. birtlessii hutA mutants are unable to establish bacteremia in their reservoir hosts. This result suggests that HutA is required for Bartonella heme uptake in mammals (Saenz et al., 2007; VayssierTaussat et al., 2010). After its transport into the cytoplasm, heme must be degraded to release iron. Ex vivo, HemS of B. henselae promotes the release of iron from heme when expressed in E. coli (Liu et al., 2012a). In vitro, HemS of B. henselae binds heme and degrades it in the presence of suitable electron donors, such as ascorbate or NADPH-cytochrome P450 reductase (Liu et al., 2012a). Interestingly, HemS activity was shown to be involved in the oxidative stress response of $B$. henselae (Liu et al., 2012a). All these above data corroborate previous ex vivo results demonstrating that Bartonella can use heme as an iron source (Sander et al., 2000). In B. quintana, expression of the hutA, hems, hutB, hutC, and hmuV is repressed by heme in an Irrdependent manner (Parrow et al., 2009). Over expression of fur in the presence of heme repress ton $B$ expression (Parrow et al., 2009).

\section{HEME-BINDING PROTEIN IN Bartonella}

Bartonella express 3-5 outer membrane heme-binding proteins (Battisti et al., 2006; Minnick and Battisti, 2009). Heme-binding proteins of Bartonella are a group of $30-40 \mathrm{kDa}$ porin-like outer membrane proteins that lack similarity with known heme receptors (Minnick et al., 2003). HbpA of B. quintana was shown to bind heme in vitro (Carroll et al., 2000). However, it did not confer a heme-binding phenotype when expressed in E. coli (Carroll et al., 2000). Zimmermann et al., identified a prominent heme-binding protein Pap31 (HbpA), through a heme-binding blot performed with membrane proteins from B. henselae. They showed that expressing Pap31 in an E. coli K12 hemA mutant strain restored its growth when heme was added at $30 \mu \mathrm{M}$ and above (Zimmermann et al., 2003). The activity of $\mathrm{HbpA}$ as a heme transporter was questioned by other authors. Recently, HbpA of B. quintana was shown to be unable to complement the E. coli hemA mutant in the presence of heme (Parrow, 2010). Complementation assays using the E. coli hemA mutant strain on solid medium in the presence of different heme concentrations also showed that HbpA of $B$. birtlessii cannot transport heme (Biville, unpublished results).

The heme uptake activity of four Hbps of B. henselae, expressed in an E. coli model strain, was investigated. All Hbps of $B$. henselae can bind heme in vitro. No heme transport activity was associated with expression of Hbps in E. coli (Liu et al., 2012b). In contrast, Hbps increase heme uptake efficiency when co-expressed with a heterologous heme transporter in an E. coli model strain (Liu et al., 2012b). Binding of heme by Hbps was proposed to increase its concentration around the bacteria and, as a consequence, facilitate its uptake. Another potential role for heme binding by Hbps was to provide an antioxidant barrier via heme's intrinsic peroxidase activity (Minnick and Battisti, 2009). Decreasing each Hbp amount using knockdown increases B. henselae sensitivity to hydrogen peroxide (Liu et al., 2012b). This antioxidant role of heme-binding proteins was evidenced to play an important role for survival of $B$. henselae in human endothelial cells and in the flea Ctenocephalides felis, where reactive oxygen species are produced. The expression levels of genes encoding for heme-binding proteins vary with oxygen, temperature and heme concentration (Battisti et al., 2006). One regulator, Irr, was shown to bind an "H-box" located in the promoter region of $h b p$ genes (Battisti et al., 2007). Also, overexpression of RirA increased expression level of $h b p A, h b p D$, and $h b p E$ (Battisti et al., 2007). Based on their regulatory pattern in B. quintana, $h b p$ genes were divided into two groups. The first contained $h b p B$ and $h b p C$, over expressed under conditions that mimic the gut arthropod environment [high heme concentration and low temperature $\left(30^{\circ} \mathrm{C}\right)$, high $\mathrm{O}_{2}$ concentration] (Battisti et al., 2006). The transcription of $h b p A, h b p D$, and $h b p E$ was increased at low heme concentrations at $37^{\circ} \mathrm{C}$. $\mathrm{HbpA}$, $\mathrm{HbpD}$, and $\mathrm{HbpE}$ were suggested as being required when the free heme concentration is low, such as in blood circulation in the mammalian host. Transcription of $B$. henselae $h b p A$ is also significantly increased at $28^{\circ} \mathrm{C}$, suggesting that $\mathrm{HbpA}$ could protect $B$. henselae from heme toxicity in the arthropod gut (Roden et al., 2012).

\section{IRON SOURCES AND OXIDATIVE STRESS ENCOUNTERED DURING Bartonella INFECTION CYCLE}

Inside the arthropod gut, Bartonella encounter high heme and oxygen levels. Such conditions can generate a massive oxidative stress. Thus, inside the arthropod gut, bacteria confront oxidative stress after a blood meal (Graca-Souza et al., 2006). Inside mammals, getting iron required for bacterial growth is a challenge since $99.9 \%$ of total body iron is sequestered inside the cells (Wandersman and Stojiljkovic, 2000). Outside the cells, iron is bound to transferrin in the serum or to lactoferrin in mucosal secretions (Cassat and Skaar, 2013). Another iron source in mammals is heme that is mainly contained in hemoproteins like hemoglobin. After erythrocyte lysis, most hemoglobin is bound by haptoglobin. Hemoglobin degradation allows the release of heme that is sequestered by hemopexin to prevent its toxicity (Wandersman and Stojiljkovic, 2000). Thus, obtaining iron from mammals requires transport systems allowing uptake of heme or iron bound to proteins. After inoculation in mammals, in the primary niche proposed to be endothelial cells, the intracellular iron source is iron $\mathrm{Fe}^{2+}$. When bacteria reach the blood stream the iron sources encountered are iron loaded transferrin, heme loaded hemopexin and hemoglobin bound to haptoglobin. Free heme is present at a low concentration $(0.5 \mu \mathrm{M})$. Bartonella does not encode for a complete iron 
uptake system and cannot transport heme bound to hemopexin. Thus, the bacteria must use heme, stored on their surface, as an iron source. Inside erythrocytes the hemoglobin concentration is high and heme can be stored in heme-binding proteins. During their life cycle, Bartonella encounter heme rich environments and heme poor environments. To face this alternation, heme-binding proteins are hypothesized to play a crucial role in storing heme in the heme rich environment, and delivering it in iron/heme poor environment. The complex regulatory expression pathway of heme-binding proteins supports this hypothesis. Bartonella express one heme transport system HutA and control heme entry and toxicity using heme storage proteins, differentially expressed according to the bacterial infection cycle. The Bartonella heme uptake and storage pathways are regulated by Irr, RirA, and Fur similar to $\alpha$-proteobacteria (Johnston et al., 2007). This iron/heme uptake pathway contrasts with that of another flea-borne pathogen Yersinia pestis.

\section{IRON/HEME UPTAKE AND HEME-BINDING PROTEINS IN Yersinia pestis}

Yersinia pestis, the causative agent of plague, is transmitted mainly by infected flea bites (Chouikha and Hinnebusch, 2012) (Figure 1). Like many highly-virulent pathogenic bacteria, $Y$. pestis possess siderophore-mediated iron acquisition systems. Yersiniabactin (Ybt), the siderophore synthesized and secreted by $Y$. pestis, can remove iron from various host iron-binding proteins, such as transferrin and lactoferrin (Fetherston et al., 2010). Fe-Ybt assimilation occurs through the TonB-dependent outer membrane receptor Psn (Lucier et al., 1996). After passage through the outer membrane, Ybt-bound iron is transported into the bacterial cell by the YbtP-YbtQ ABC transporter (Fetherston et al., 1999). In Y. pestis, iron $\mathrm{Fe}^{2+}$ is transported by the YfeABCD and FeoABC systems (Perry et al., 2007). Also, $Y$. pestis encode for two heme transport systems. The hmu locus (hmuRSTUV) allows $Y$. pestis to use heme as well as host hemoproteins including hemoglobin, myoglobin, hemealbumin, heme-hemopexin, and hemoglobin-haptoglobin as an iron source (Hornung et al., 1996) (Figure 2). The second hemeprotein acquisition system consisted of a heme receptor HasR, HasA hemophore, and HasA-dedicated ABC transporter factor HasDE, as well as a TonB homolog, HasB. However, the Has system appears not to allow the bacteria to use hemoglobin as an iron source under laboratory conditions (Rossi et al., 2001). In $Y$. pestis, the iron and heme uptake systems are Fur regulated (Gao et al., 2008). Y. pestis's main transmission mode depends on the flea foregut blockage (Hinnebusch et al., 1996; Chouikha and Hinnebusch, 2012) resulting in continuous attempts to feed (Figure 1). Thus, the contaminated blood is regurgitated back into the mammalian host, where the bacteria rapidly establish an infection (Hinnebusch et al., 1996). Blockage of the flea foregut requires the activity of hmsHFRS gene products which synthesize and export the polysaccharide extracellular matrix required for formation of biofilm (Bobrov et al., 2008). Biofilm formation at the surface of proventricular spines is required for infection of the proventriculus (Jarrett et al., 2004). The Hms system is responsible for absorption of exogenous heme or Congo red when the bacteria are grown at $26^{\circ} \mathrm{C}$ (Burrows and Jackson, 1956; Surgalla and Beesley, 1969). However, the Hms system never encodes for a heme uptake system. Moreover, the stockpiled heme is not used under irondeficient conditions (Lillard et al., 1999). Consistently, a deletion of the Hms system has no effect on $Y$. pestis virulence in mice infected by a subcutaneous route. This indicated that the Hms system is not required for the virulence of bubonic plague in a mouse model (Lillard et al., 1999). The Hms heme storage system is essential for establishing an infection within the flea midgut and to block the proventriculus (Hinnebusch et al., 1996). Heme absorbed by the Hms system protects Y. pestis from the nitric oxide and superoxide anion toxicity, but not from the $\mathrm{H}_{2} \mathrm{O}_{2}$ killing effect (Lillard et al., 1999). $\mathrm{HmsH}$ and $\mathrm{HmsF}$ were
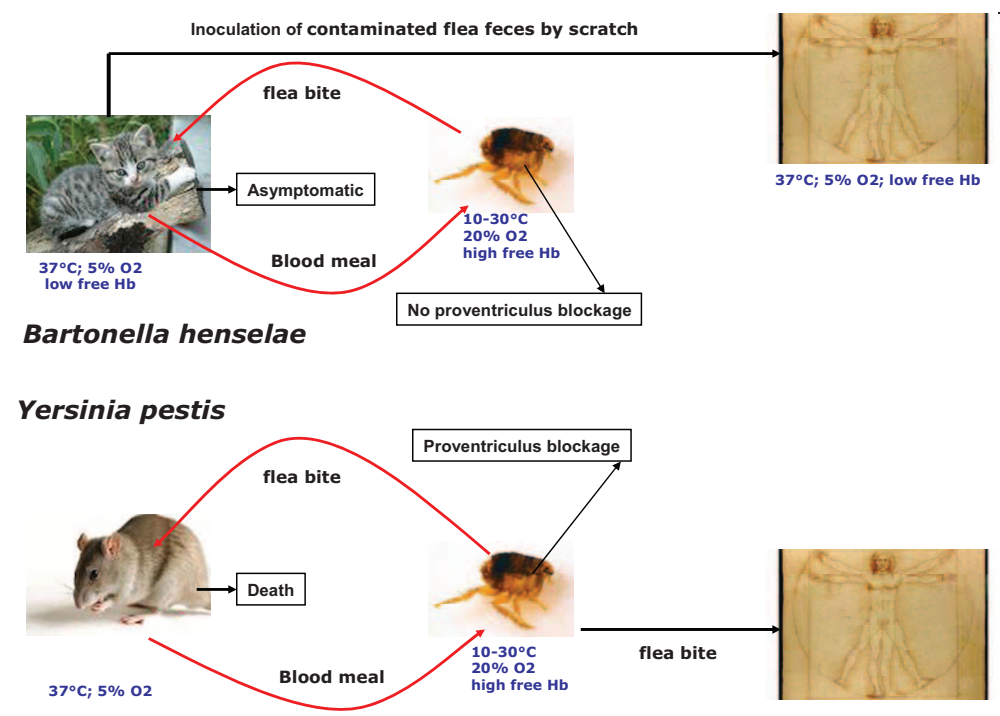

FIGURE 1 | Comparison of Bartonella henselae and Yersinia pestis transmission modes. 


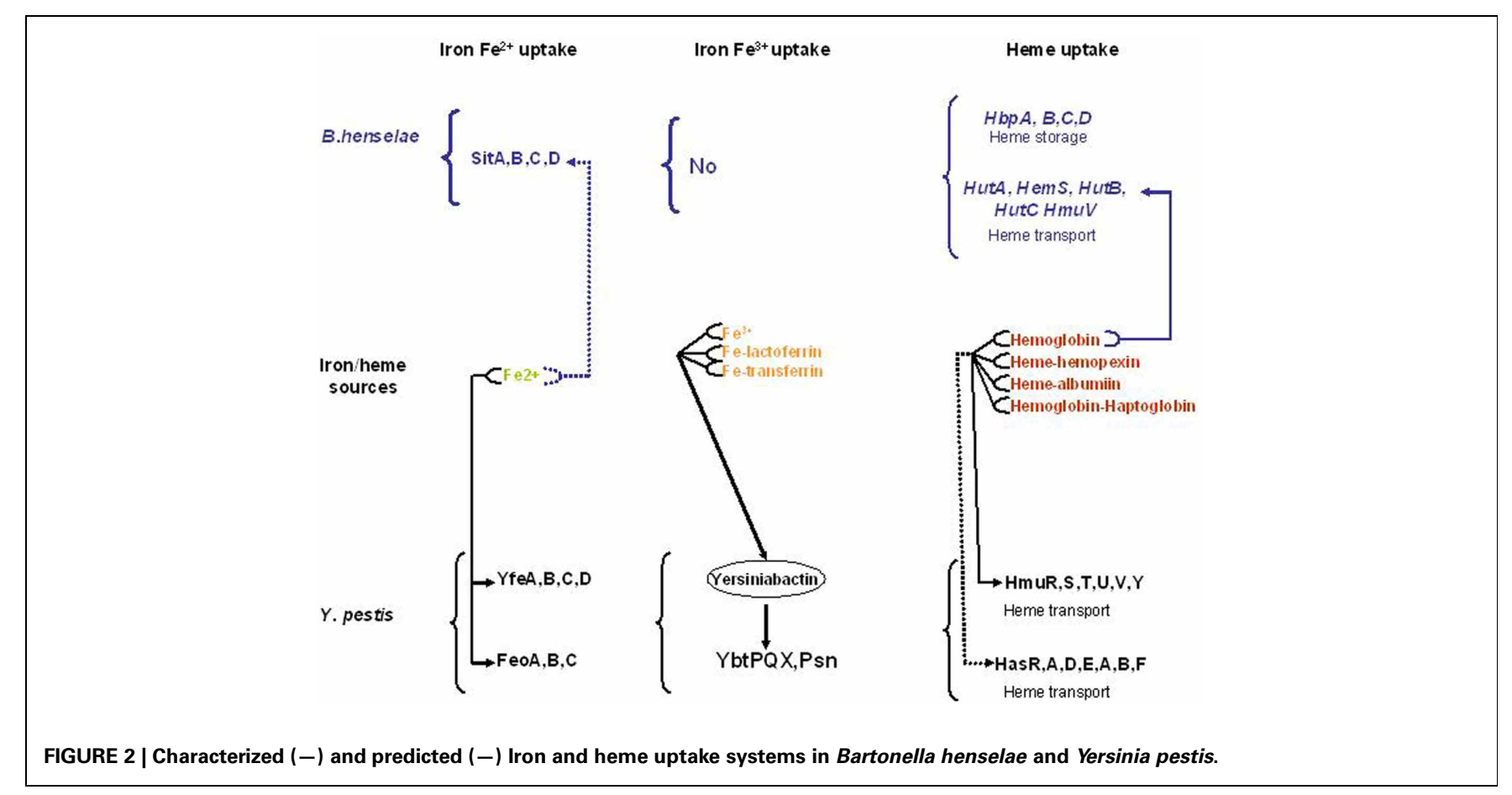

characterized as outer membrane proteins (Pendrak and Perry, 1991) while HmsR, HmsS, and HmsT are inner membrane proteins (Perry et al., 2004). HmsF and HmsR possess domains found in polysaccharide-modifying enzymes and glycosyltransferases, respectively, and HmsT belongs to the family of GGDEF proteins (Lillard et al., 1997; Ausmees et al., 2001; Perry et al., 2004). Transcription of heme acquisition operon hmsHFRS and $h m s T$ is not regulated by the iron status inside the cells and the availability of exogenous heme (Perry et al., 2004). The temperature-dependent regulation of $\mathrm{HmsH}, \mathrm{HmsF}, \mathrm{HmsR}$, and HmsT amount is post transcriptional and is related to a decreased stability of these proteins at $37^{\circ} \mathrm{C}$ (Perry et al., 2004).

\section{CONCLUSION}

The two flea-borne pathogens $B$. henselae and $Y$. pestis can invade the flea gut and mammals. As a consequence, they must adapt their physiology to face the change related to these two environments. Inside the flea gut, bacteria can use heme as an iron source and must face its toxicity. Flea bite is responsible for $Y$. pestis transmission and $B$. henselae can also be transmitted by flea feces contamination (Figure 1). This transmission mode is possible since $B$. henselae is able to survive several days within feces. Inside the flea gut, Y. pestis forms a biofilm in the proventriculus responsible for blocking. Blocking and biofilm formation have not been described for $B$. henselae. Inside mammals, $Y$. pestis can use different iron and heme sources (Figure 2). In contrast, the sole iron/heme source for $B$. henselae, outside the cells, is heme contained in hemoglobin (Figure 2). Inside the cells, B. henselae could use the reduced form of iron. For $B$. henselae, the ability to invade erythrocytes is thus a good opportunity to obtain heme. In Y. pestis, no heme transport activity was associated with $\mathrm{HmsH}, \mathrm{HmsF}, \mathrm{HmsR}$, and HmsT. Moreover, heme absorbed by the Hms system is not used as an iron source (Lillard et al., 1999). In contrast, heme-binding proteins from $B$. henselae were shown to increase the heme uptake efficiency. Inside the flea, the presence of all heme-binding proteins is required for $B$. henselae survival. The pathogenesis of $Y$. pestis is not affected by the absence of a heme storage phenotype. In contrast, disruption of one heme-binding protein in Bartonella impairs bacteremia establishment. In regard to the cell invasion $B$. henselae and $Y$. pestis exhibit a similar phenotype since HpbA knockdown in $B$. henselae and $\mathrm{Hms}^{-}$phenotype in Y. pestis decrease the ability to invade cells (Lillard et al., 1999; Liu et al., 2012b). Both in Y. pestis and $B$. henselae the heme storage phenotype was evidenced to be involved in protection against oxidative stress. In $B$. henselae, all heme-binding proteins were associated with protection against oxidative stress generated by exposure to hydrogen peroxide. In $Y$. pestis, $\mathrm{Hms}^{-}$phenotype decreases the ability to face exposure to paraquat.

For Bartonella, the ability to store heme looks like it is more crucial than that for Y. pestis. This could explain why small Bartonella genomes (Alsmark et al., 2004) encode for 3-5 highly homologous heme-binding proteins whose expression level is submitted to a complex regulatory pathway (Battisti et al., 2007). Since heme storage is a very important process for Bartonella, this can explain why decreasing the amount of only one heme-binding protein generates some defects in spite of the presence of others heme-binding proteins. In addition to the regulatory events managing expression of the various $h b p$ genes, it cannot be excluded that heme-binding proteins coordinate their activity. A precise biochemical characterization of heme-binding proteins will give fruitful information about a possible cooperative activity of these outer membrane proteins. 


\section{REFERENCES}

Alsmark, C. M., Frank, A. C., Karlberg, E. O., Legault, B. A., Ardell, D. H., Canback, B., et al. (2004). The louse-borne human pathogen Bartonella quintana is a genomic derivative of the zoonotic agent Bartonella henselae. Proc. Natl. Acad. Sci. U.S.A. 101, 9716-9721. doi: 10. 1073/pnas.0305659101

Anjem, A., Varghese, S., and Imlay, J. A. (2009). Manganese import is a key element of the OxyR response to hydrogen peroxide in Escherichia coli. Mol. Microbiol. 72, 844-858. doi: 10.1111/j.1365-2958. 2009.06699.x

Ausmees, N., Mayer, R., Weinhouse, H., Volman, G., Amikam, D., Benziman, M., et al. (2001). Genetic data indicate that proteins containing the GGDEF domain possess diguanylate cyclase activity. FEMS Microbiol. Lett. 204, 163-167. doi: 10.1111/j.15746968.2001.tb10880.x

Battisti, J. M., Sappington, K. N., Smitherman, L. S., Parrow, N. L., and Minnick, M. F. (2006). Environmental signals generate a differential and coordinated expression of the heme receptor gene family of Bartonella quintana. Infect. Immun. 74, 3251-3261. doi: 10.1128/IAI.00245-06

Battisti, J. M., Smitherman, L. S., Sappington, K. N., Parrow, N. L., Raghavan, R., and Minnick, M. F. (2007). Transcriptional regulation of the heme binding protein gene family of Bartonella quintana is accomplished by a novel promoter element and iron response regulator. Infect. Immun. 75, 4373-4385. doi: 10.1128/IAI.00497-07

Bobrov, A. G., Kirillina, O., Forman, S., Mack, D., and Perry, R. D. (2008). Insights into Yersinia pestis biofilm development: topology and co-interaction of $\mathrm{Hms}$ inner membrane proteins involved in exopolysaccharide production. Environ. Microbiol. 10, 1419-1432. doi: $\quad 10.1111 /$ j.1462-2920.2007. 01554.x

Boulouis, H. J., Barrat, F., Bermond, D., Bernex, F., Thibault, D., Heller, R., et al. (2001). Kinetics of Bartonella birtlesii infection in experimentally infected mice and pathogenic effect on reproductive functions. Infect. Immun. 69, 5313-5317. doi: 10.1128/IAI.69.9. 5313-5317.2001

Burrows, T. W., and Jackson, S. (1956). The pigmentation of Pasteurella pestis on a defined medium containing haemin. Br. J. Exp. Pathol. 37, 570-576.
Carroll, J. A., Coleman, S. A., Smitherman, L. S., and Minnick, M. F. (2000). Hemin-binding surface protein from Bartonella quintana. Infect. Immun. 68, 6750-6757. doi: 10.1128/IAI.68.12. 6750-6757.2000

Cassat, J. E., and Skaar, E. P. (2013). Iron in infection and immunity. Cell Host Microbe 13, 509-519. doi: 10.1016/j.chom.2013.04.010

Chomel, B. B., Boulouis, H. J., Breitschwerdt, E. B., Kasten, R. W., Vayssier-Taussat, M., Birtles, R. J., et al. (2009). Ecological fitness and strategies of adaptation of Bartonella species to their hosts and vectors. Vet. Res. 40, 29. doi: $10.1051 /$ vetres/2009011

Chouikha, I., and Hinnebusch, B. J. (2012). Yersinia-flea interactions and the evolution of the arthropodborne transmission route of plague. Curr. Opin. Microbiol. 15, 239-246. doi: 10.1016/j.mib.2012.02.003

Dehio, C. (2005). Bartonella-host-cell interactions and vascular tumour formation. Nat. Rev. Microbiol. 3, 621-631. doi: 10.1038/nrmicro1209

Dehio, C., and Sander, A. (1999). Bartonella as emerging pathogens. Trends Microbiol. 7, 226-228. doi: 10.1016/S0966-842X(99)01523-1

Fetherston, J. D., Bertolino, V. J., and Perry, R. D. (1999). YbtP and YbtQ: two $\mathrm{ABC}$ transporters required for iron uptake in Yersinia pestis. Mol. Microbiol. 32, 289-299. doi: 10.1046/j.1365-2958.1999.01348.x

Fetherston, J. D., Kirillina, O., Bobrov, A. G., Paulley, J. T., and Perry, R. D. (2010). The yersiniabactin transport system is critical for the pathogenesis of bubonic and pneumonic plague. Infect. Immun. 78, 2045-2052. doi: 10.1128/IAI. 01236-09

Florin, T. A., Zaoutis, T. E., and Zaoutis, L. B. (2008). Beyond cat scratch disease: widening spectrum of Bartonella henselae infection. Pediatrics 121, e1413-e1425. doi: 10.1542/peds.2007-1897

Gao, H., Zhou, D., Li, Y., Guo, Z., Han, Y., Song, Y., et al. (2008). The ironresponsive Fur regulon in Yersinia pestis. J. Bacteriol. 190, 3063-3075. doi: 10.1128/JB.01910-07

Graca-Souza, A. V., Maya-Monteiro, C., Paiva-Silva, G. O., Braz, G. R., Paes, M. C., Sorgine, M. H., et al. (2006). Adaptations against heme toxicity in blood-feeding arthropods. Insect. Biochem. Mol. Biol. 36, 322-335. doi: 10.1016/j.ibmb.2006. 01.009

Guptill, L. (2010). Bartonellosis. Vet. Microbiol. 140, 347-359. doi: 10.1016/j.vetmic.2009.11.011
Herrer, A. (1953a). Carrion's disease. II. Presence of Bartonella bacilliformis in the peripheral blood of patients with the benign form. Am. J. Trop. Med. Hyg. 2, 645-649.

Herrer, A. (1953b). Carrion's disease I. Studies on plants claimed to be reservoirs of Bartonella bacilliformis. Am. J. Trop. Med. Hyg. 2, 637-643.

Hill, E. M., Raji, A., Valenzuela, M. S., Garcia, F., and Hoover, R. (1992). Adhesion to and invasion of cultured human cells by Bartonella bacilliformis. Infect. Immun. 60 , 4051-4058.

Hinnebusch, B. J., Perry, R. D., and Schwan, T. G. (1996). Role of the Yersinia pestis hemin storage (hms) locus in the transmission of plague by fleas. Science 273, 367-370. doi: 10.1126/science.273.5273.367

Hornung, J. M., Jones, H. A., and Perry, R. D. (1996). The hmu locus of Yersinia pestis is essential for utilization of free haemin and haem-protein complexes as iron sources. Mol. Microbiol. 20, 725-739. doi: 10.1111/j.13652958.1996.tb02512.x

Jarrett, C. O., Deak, E., Isherwood, K. E., Oyston, P. C., Fischer, E R., Whitney, A. R., et al. (2004). Transmission of Yersinia pestis from an infectious biofilm in the flea vector. J. Infect. Dis. 190, 783-792. doi: 10.1086/422695

Johnston, A. W., Todd, J. D., Curson, A R., Lei, S., Nikolaidou-Katsaridou, N., Gelfand, M. S., et al. (2007). Living without Fur: the subtlety and complexity of iron-responsive gene regulation in the symbiotic bacterium Rhizobium and other alpha-proteobacteria. Biometals 20, 501-511. doi: 10.1007/s10534-0079085-8

Jones, P. D. (1993). Cat scratch disease and Rochalimaea henselae. Med. J. Aust. 159, 211.

Kaiser, P. O., Riess, T., O’Rourke, F. Linke, D., and Kempf, V. A. (2011). Bartonella spp: throwing light on uncommon human infections. Int J. Med. Microbiol. 301, 7-15. doi: 10.1016/j.ijmm.2010.06.004

Koesling, J., Aebischer, T., Falch, C. Schulein, R., and Dehio, C. (2001). Cutting edge: antibody-mediated cessation of hemotropic infection by the intraerythrocytic mouse pathogen Bartonella grahamii. J. Immunol. 167, 11-14.

Lillard, J. W. Jr., Bearden, S. W., Fetherston, J. D., and Perry, R. D. (1999). The haemin storage (Hms+) phenotype of Yersinia pestis is not essential for the pathogenesis of bubonic plague in mammals.
Microbiology 145(Pt 1), 197-209. doi: 10.1099/13500872-145-1-197

Lillard, J. W. Jr., Fetherston, J. D., Pedersen, L., Pendrak, M. L., and Perry, R. D. (1997). Sequence and genetic analysis of the hemin storage (hms) system of Yersinia pestis. Gene 193, 13-21. doi: 10.1016/S03781119(97)00071-1

Liu, M., Boulouis, H. J., and Biville, F. (2012a). Heme degrading protein HemS is involved in oxidative stress response of Bartonella henselae. PLoS ONE 7:e37630. doi: 10.1371/journal.pone.0037630

Liu, M., Ferrandez, Y., Bouhsira, E., Monteil, M., Franc, M., Boulouis, H. J., et al. (2012b). Heme binding proteins of Bartonella henselae are required when undergoing oxidative stress during cell and flea invasion. PLoS ONE 7:e48408. doi: 10.1371/journal.pone.0048408

Lucier, T. S., Fetherston, J. D., Brubaker, R. R., and Perry, R. D. (1996). Iron uptake and iron-repressible polypeptides in Yersinia pestis. Infect. Immun. 64, 3023-3031.

Mandle, T., Einsele, H., Schaller, M., Neumann, D., Vogel, W., Autenrieth, I. B., et al. (2005). Infection of human CD34+ progenitor cells with Bartonella henselae results in intraerythrocytic presence of $B$. henselae. Blood 106, 1215-1222. doi: 10.1182/blood-2004-12-4670

Marignac, G., Barrat, F., Chomel, B., Vayssier-Taussat, M., Gandoin, C., Bouillin, C., et al. (2010). Murine model for Bartonella birtlesii infection: new aspects. Comp. Immunol. Microbiol. Infect. Dis. 33, 95-107. doi: 10.1016/j.cimid.2008. 07.011

Maurin, M., and Raoult, D. (1996). Bartonella (Rochalimaea) quintana infections. Clin. Microbiol. Rev. 9, 273-292.

Minnick, M. F., and Battisti, J. M. (2009). Pestilence, persistence and pathogenicity: infection strategies of Bartonella. Future Microbiol. 4, 743-758. doi: 10.2217/fmb.09.41

Minnick, M. F., Sappington, K. N., Smitherman, L. S., Andersson, S. G., Karlberg, O., and Carroll, J. A. (2003). Five-member gene family of Bartonella quintana. Infect. Immun. 71, 814-821. doi: 10.1128/IAI.71.2.814-821.2003

Parrow, N. L., Abbott, J., Lockwood, A. R., Battisti, J. M., and Minnick, M. F. (2009). Function, regulation, and transcriptional organization of the hemin utilization locus of Bartonella quintana. Infect. Immun. 77, 307-316. doi: 10.1128/IAI.01194-08 
Parrow, N. L. (2010). Hemin Acquisition in Bartonella quintana. $\mathrm{PhD}$ Dissertation. Available online at: http://etd.lib.theses/available/etd-03 102010-110543/unrestricted/Parro w_umt_0136D_10080.pdf

Pendrak, M. L., and Perry, R. D. (1991). Characterization of a hemin-storage locus of Yersinia pestis. Biol. Met. 4, 41-47. doi: 10.1007/BF01135556

Perry, R. D., Bobrov, A. G., Kirillina, O., Jones, H. A., Pedersen, L., Abney, J., et al. (2004). Temperature regulation of the hemin storage (Hms+) phenotype of Yersinia pestis is posttranscriptional. J. Bacteriol. 186, 1638-1647. doi: 10.1128/JB.186.6. 1638-1647.2004

Perry, R. D., Mier, I., Jr., and Fetherston, J. D. (2007). Roles of the Yfe and Feo transporters of Yersinia pestis in iron uptake and intracellular growth. Biometals 20, 699-703. doi: 10.1007/s10534-006-9051-x

Roden, J. A., Wells, D. H., Chomel, B. B., Kasten, R. W., and Koehler, J. E. (2012). Hemin binding protein C is found in outer membrane vesicles and protects Bartonella henselae against toxic concentrations of hemin. Infect. Immun. 80, 929-942. doi: 10.1128/IAI.05769-11

Rossi, M. S., Fetherston, J. D., Letoffe, S., Carniel, E., Perry, R. D., and Ghigo, J. M. (2001). Identification and characterization of the hemophore-dependent heme acquisition system of Yersinia pestis. Infect. Immun. 69, 6707-6717. doi: 10.1128/IAI.69.11.6707-6717.2001
Sabri, M., Leveille, S., and Dozois, C. M. (2006). A SitABCD homologue from an avian pathogenic Escherichia coli strain mediates transport of iron and manganese and resistance to hydrogen peroxide. Microbiology 152(Pt 3), 745-758. doi: 10.1099/mic.0. 28682-0

Saenz, H. L., Engel, P., Stoeckli, M. C., Lanz, C., Raddatz, G., VayssierTaussat, M., et al. (2007). Genomic analysis of Bartonella identifies type IV secretion systems as host adaptability factors. Nat. Genet. 39, 1469-1476. doi: 10.1038/ng.2007.38

Sander, A., Kaliebe, T., and Bredt, W. (1996). [Bartonella (Rochalimaea) infections: cat-scratch disease and bacillary angiomatosis]. Dtsch. Med. Wochenschr. 121, 65-69. doi: 10.1055/s-2008-1042973

Sander, A., Kretzer, S., Bredt, W., Oberle, K., and Bereswill, S. (2000). Hemin-dependent growth and hemin binding of Bartonella henselae. FEMS Microbiol. Lett. 189, 55-59. doi: 10.1111/j.15746968.2000.tb09205.x

Schroder, G., and Dehio, C. (2005). Virulence-associated type IV secretion systems of Bartonella. Trends Microbiol. 13, 336-342. doi: 10.1016/j.tim.2005.05.008

Schulein, R., Seubert, A., Gille, C., Lanz, C., Hansmann, Y., Piemont, Y., et al. (2001). Invasion and persistent intracellular colonization of erythrocytes. A unique parasitic strategy of the emerging pathogen Bartonella. J. Exp. Med. 193, 1077-1086. doi: 10.1084/jem. 193.9.1077

Spach, D. H., Kanter, A. S., Dougherty, M. J., Larson, A. M., Coyle, M. B., Brenner, D. J., et al. (1995). Bartonella (Rochalimaea) quintana bacteremia in inner-city patients with chronic alcoholism. N. Engl. J. Med. 332, 424-428. doi: 10.1056/ NEJM199502163320703

Surgalla, M. J., and Beesley, E. D. (1969). Congo red-agar plating medium for detecting pigmentation in Pasteurella pestis. Appl. Microbiol. 18, 834-837.

Vayssier-Taussat, M., Le Rhun, D., Deng, H. K., Biville, F., Cescau, S., Danchin, A., et al. (2010). The Trw type IV secretion system of Bartonella mediates hostspecific adhesion to erythrocytes. PLoS Pathog. 6:e1000946. doi: 10.1371/journal.ppat.1000946

Vinson, J. W., Varela, G., and MolinaPasquel, C. (1969). Trench fever. 3. Induction of clinical disease in volunteers inoculated with Rickettsia quintana propagated on blood agar. Am. J. Trop. Med. Hyg. 18, 713-722.

Wandersman, C., and Stojiljkovic, I. (2000). Bacterial heme sources: the role of heme, hemoprotein receptors and hemophores. Curr. Opin. Microbiol. 3, 215-220. doi 10.1016/S1369-5274(00)00078-3

Zimmermann, R., Kempf, V. A. Schiltz, E., Oberle, K., and
Sander, A. (2003). Hemin binding, functional expression, and complementation analysis of Pap 31 from Bartonella henselae. J. Bacteriol. 185, 1739-1744. doi: 10.1128/JB.185.5.1739-1744.2003

Conflict of Interest Statement: The authors declare that the research was conducted in the absence of any commercial or financial relationships that could be construed as a potential conflict of interest.

Received: 17 July 2013; paper pending published: 01 August 2013; accepted: 19 September 2013; published online: 18 October 2013.

Citation: LiuM and Biville F (2013) Managing iron supply during the infection cycle of a flea borne pathogen, Bartonella henselae. Front. Cell. Infect. Microbiol. 3:60. doi: 10.3389/fcimb 2013.00060

This article was submitted to the journal Frontiers in Cellular and Infection Microbiology.

Copyright (c) 2013 Liu and Biville. This is an open-access article distributed under the terms of the Creative Commons Attribution License (CC BY). The use, distribution or reproduction in other forums is permitted, provided the original author(s) or licensor are credited and that the original publication in this journal is cited, in accordance with accepted academic practice. No use, distribution or reproduction is permitted which does not comply with these terms. 